\title{
A comparison of animal output and nitrogen leaching losses recorded from drained fertilized grass and grass/clover pasture
}

\author{
K. C. TYSON, D. SCHOLEFIELD, S. C. JARVIS And A. C. STONE \\ Institute of Grassland and Environmental Research, North Wyke, Okehampton, Devon EX20 2SB, UK
}

(Revised MS received 10 March 1997)

\section{SUMMARY}

Annual liveweight gain of beef cattle (steers) grazing grass pasture fertilized with $200 \mathrm{~kg} \mathrm{~N} / \mathrm{ha}$ was compared over a period of 7 years (1989-95) with that of steers grazing grass/white clover pasture given no artificial $\mathrm{N}$ fertilizer at North Wyke, Devon, UK. Nitrogen lost by leaching over the ensuing winter drainage periods was monitored from both pastures. Nitrogen leaching loss from the fertilized pasture over an extended period of 13 years (1983-95) is also reported.

The average annual liveweight gain of the steers grazing the grass/clover pasture $(0 \cdot 81 \mathrm{t} / \mathrm{ha})$ was $19 \%$ lower than that of the steers grazing the $\mathrm{N}$-fertilized grass pasture $(1.00 \mathrm{t} / \mathrm{ha})$. The average annual loss of nitrate- $\mathrm{N}$ by leaching in winter drainage from the grass/clover pasture $(13 \mathrm{~kg} / \mathrm{ha}) \mathrm{was}$ only $26 \%$ of that recorded from the fertilized grass $(50 \mathrm{~kg} / \mathrm{ha})$. A possible reason for this difference may arise from the previous history of the grass/clover pasture which had been ploughed in 1982, causing a flush of $\mathrm{N}$ mineralization and consequently greater immobilization of $\mathrm{N}$ in the soil in subsequent years.

Losses of $\mathrm{N}$ each winter by leaching measured over a 13 -year period from the fertilized grass were highly correlated $(P<0.001)$ with the preceding summer's soil moisture deficit, with the highest losses following dry summers. The nitrate- $\mathrm{N}$ concentration in the drainage water exceeded the European Union limit in drinking water $(11.3 \mathrm{mg} / \mathrm{l})$ in the initial $25 \mathrm{~mm}$ of drainage during 11 of the 13 autumns. The average loss of $\mathrm{N}$ each winter $(53 \mathrm{~kg} / \mathrm{ha})$ was equivalent to $26 \%$ of the fertilizer- $\mathrm{N}$ applied annually. Immediate losses of $\mathrm{N}$ by leaching of fertilizer applied in early spring and throughout one very wet summer (1993) were minimal.

\section{INTRODUCTION}

In previous papers describing the grassland drainage experiment at North Wyke, Devon (Tyson et al. $1992 a$; Scholefield et al. 1993), we have shown that drainage of these impermeable clay soils, known locally as the Culm Measures, increased annual liveweight production of grazing cattle by only $11 \%$. This increase in output was not statistically significant and was unlikely to be economic for beef production in the short term because of the high initial capital cost of drainage schemes. Drainage of these soils was also shown to have potentially serious environmental side-effects. Nitrogen $(\mathrm{N})$ leached from the grazed pastures was more than three times greater from the drained pasture compared with that recorded from undrained pasture receiving the same annual input of fertilizer-N. Nitrogen lost to drainage as nitrate $\left(\mathrm{NO}_{3}-\mathrm{N}\right)$ from pasture receiving an annual fertilizer$\mathrm{N}$ input of $200 \mathrm{~kg} / \mathrm{ha}$ was increased over the ensuing winter periods from an average of $16 \mathrm{~kg} / \mathrm{ha}$ from undrained paddocks to $56 \mathrm{~kg} / \mathrm{ha}$ from drained paddocks (Scholefield et al. 1993; Tyson et al. 1993).

In lowland southern and eastern England, clover is generally accepted as being capable of fixing some $74-280 \mathrm{~kg} / \mathrm{ha}$ of atmospheric $\mathrm{N}$ annually (Cowling 1982) and therefore the productivity of pastures with a substantial clover content could be expected to be comparable to that of a grass pasture supplied with moderate rates of fertilizer-N. In this experiment, steer production and $\mathrm{N}$ leaching losses from grass/ clover pasture were compared with those recorded from the grass pasture receiving $200 \mathrm{~kg} \mathrm{~N} /$ ha. During 1988, two drained paddocks sown originally to perennial ryegrass (Lolium perenne L.) in 1982 and receiving $400 \mathrm{~kg} \mathrm{~N} /$ ha annually over the 5-year period 1983-87 were converted to grass/white clover (Trifolium repens L.) pastures and have since received no fertilizer-N. This paper reports on the 7-years' data on steer production and $\mathrm{N}$ losses by leaching 
from this and the drained grass pasture with $200 \mathrm{~kg}$ $\mathrm{N} /$ ha. Also reported are the $\mathrm{N}$ leaching losses from the fertilized grass pasture recorded over a longer period of 13 years.

\section{MATERIALS AND METHODS}

The Rowden drainage experiment has been fully described in previous papers. The soils of the experimental area were surveyed by Harrod (1981) and a full description of the drainage treatments and hydrological instrumentation, together with the results of drainage on the soil water regimes, are given by Armstrong \& Garwood (1991). Agronomic results obtained during the first 5 years of the experiment (1983-87) were reported by Tyson et al. (1992a) and a further paper by Scholefield et al. (1993) provided detailed information and analysis of the $\mathrm{N}$ losses recorded in drainage water from the various experimental treatments during 1983-89. A technical report by Tyson et al. (1993) provided the historic record, scientific data obtained and conclusions derived over the 10-year period, 1983-92. A 'popular' article (Tyson et al. 1992b) summarized the main practical implications obtained from the experiment.

Two drained 1 ha sized paddocks previously sown to perennial ryegrass (cv. Melle) and receiving $400 \mathrm{~kg}$ $\mathrm{N} /$ ha were converted to grass/clover pastures during 1988 using a Hunter rotary strip seeder (Pascal \& Sheppard 1985) as follows. Nitrogen was applied on 14 March, 11 April and 5 May in equal amounts, giving a total of $132 \mathrm{~kg} / \mathrm{ha}$. The paddocks were cut for silage on 1 June and then sprayed on 8 June with paraquat (at 1.4 litres/ha) to suppress grass regrowth. On 13 June, white clover (cv. Menna) was stripseeded into the sward at $4.8 \mathrm{~kg} / \mathrm{ha}$. Slug pellets at $3.6 \mathrm{~kg} / \mathrm{ha}$, lime at $63 \mathrm{~kg} / \mathrm{ha}$, phosphorus at $30 \mathrm{~kg} / \mathrm{ha}$ and potassium at $60 \mathrm{~kg} / \mathrm{ha}$ were also strip-seeded into the sward with the clover seed. The summer of 1988 was one of the wettest recorded at North Wyke and consequently both germination of clover seed and subsequent clover growth were good. The pastures were sprayed on 22 June with chlorpyrifos (Dursban, Dow Elanco) to prevent any possible attack by Sitona weevils on the germinating clover seedlings. No further $\mathrm{N}$ was applied in 1988 or during the subsequent 7 years. The grass/clover pastures were lightly grazed by steers from mid-July until late October during this establishment year.

The fertilized grass pastures were originally established in 1982 on a permanent pasture known to be at least 50 years old and treatments remained substantially unchanged throughout the course of the present measurements. Total annual $\mathrm{N}$ input (200 kg/ha) remained unchanged. Between 1983 and 1992, fertilizer was applied in nine equal amounts of $22 \cdot 2 \mathrm{~kg} / \mathrm{ha}$ starting in mid-March and thereafter at 3 -weekly intervals. During the last 3 years (1993-95),
$40 \mathrm{~kg} / \mathrm{ha}$ was applied in the first and second applications in mid-March and mid-April followed by four equal applications of $30 \mathrm{~kg} / \mathrm{ha}$ at monthly intervals until mid-August. Each spring, $25 \mathrm{~kg} \mathrm{P} / \mathrm{ha}$ and $50 \mathrm{~kg}$ $\mathrm{K} / \mathrm{ha}$ was applied to the grass treatments and for the first 3 years (1989-91) $50 \mathrm{~kg} \mathrm{P} / \mathrm{ha}$ and $100 \mathrm{~kg} \mathrm{~K} / \mathrm{ha}$ was applied each spring to the grass/clover treatments. This rate was reduced in 1992 to $40 \mathrm{~kg} \mathrm{P} / \mathrm{ha}$ and $80 \mathrm{~kg}$ $\mathrm{K} / \mathrm{ha}$ and subsequently to $25 \mathrm{~kg} \mathrm{P} / \mathrm{ha}$ and $50 \mathrm{~kg}$ $\mathrm{K} /$ ha during 1993-95 in response to the increase in available $\mathrm{P}$ and $\mathrm{K}$. Soil $\mathrm{pH}$ remained in the range $6 \cdot 0-6 \cdot 5$ in the $0-10 \mathrm{~cm}$ soil horizon of both grass and grass/clover pastures and so no lime was applied after 1988. Each of the paddocks had been mole drained (at $2 \mathrm{~m}$ spacing) in 1982. They were re-moled during the summer of 1987 and again in August 1993. All plots were grazed by Limousin $\times$ Friesian beef steers (average weight $275-300 \mathrm{~kg}$ at turnout). Animal numbers were adjusted as required throughout each season, to maintain sward heights in the range 50-60 $\mathrm{mm}$ (risingplate sward stick; Holmes 1974).

Herbage production was estimated at 3-week intervals during the period 1989-92 by taking sample cuts from under exclusion cages as described by Tyson et al. (1993). To allow for variable soil contamination, subsamples of herbage were analysed for ash content and herbage yields were expressed as ash-free organic matter (OM). Estimates of clover content were made on hand-separated subsamples of fresh herbage. Estimates of herbage organic matter (OM) yield and clover content were discontinued after 1992. Steer liveweight gain (LWG) from the two contrasting pastures was measured by the regular weighing of five core steers allocated to each paddock as described by Tyson et al. (1992a). The steers used in 1989-91, but not subsequently, were each given a 'Romensin' ruminal delivery device containing monensin sodium to comply with current farm practice at that time.

Each paddock was hydrologically isolated from its neighbours with drainage water directed through a weir. Samples of drainage water were collected daily from the outfall of the weirs throughout the winter period when the soil was at field capacity. These samples were analysed for nitrate + nitrite-N (Hendriksen \& Selmer Olsen 1970) and ammonium-N $\left(\mathrm{NH}_{4}-\mathrm{N}\right)$ (Searle 1984), and the quantities of $\mathrm{N}$ lost to drainage calculated by the methods described by Scholefield et al. (1993) using weekly values of drainage calculated from incoming rainfall less the estimate for evapotranspiration.

A measure of each growing season's wetness or dryness can be inferred from the maximum potential soil water deficit (SWD). This value was derived from the daily rainfall and evaporation of surface water from a $4 \mathrm{~m}^{2}$ tank, using seasonal correction factors to adjust to transpiration by a grass sward freely supplied with water (Penman 1952). Drainage data have been 
derived from rainfall minus evapotranspiration from the date drainage first commenced each autumn until its cessation the following spring.

\section{RESULTS}

\section{Rainfall and water balances}

North Wyke Research Station received an average $1054 \mathrm{~mm}$ rain each year for the 30-year period, 1966-95. The wettest months were December $(130 \mathrm{~mm})$ and January $(134 \mathrm{~mm})$ whereas the driest month was July $(54 \mathrm{~mm})$. Despite the high annual rainfall, a considerable SWD often built up during the growing season, causing periods of restricted grass growth during some summers (Table 1). The years with a large potential SWD (i.e. $>250 \mathrm{~mm}$ ) were 1983, 1984, 1989, 1990 and 1995. Wetter summers with a low potential SWD (i.e. $<105 \mathrm{~mm}$ ) were 1986, 1988 and especially 1993, when drainage was recorded during periods of all the summer months except August.

\section{Herbage organic matter $(O M)$ yield}

Organic matter yields of both grass $+\mathrm{N}$ and grass/ clover pastures were low during the two dry summers of 1989 and 1990 (Table 2). Although over the 4-year period of measurements, the grass $+\mathrm{N}$ pasture outyielded the grass/clover pasture by $19 \%$, in 1991 (the year with the highest clover content) the grass/clover pasture produced the larger OM yield. Clover content
Table 2. Annual organic matter $(O M)$ yield from grass $+200 \mathrm{~kg} \mathrm{~N}$ and grass/clover pasture $(\mathrm{t} / \mathrm{ha})$ and percentage contribution of clover (in parentheses) to the grass/clover yield. Values are means of two replicates

\begin{tabular}{lcl}
\hline \hline Year & Grass $+\mathrm{N}$ & Grass/clover \\
\hline 1989 & $6 \cdot 88$ & $4 \cdot 28(9 \%)$ \\
1990 & $6 \cdot 75$ & $5 \cdot 30(28 \%)$ \\
1991 & $8 \cdot 09$ & $8 \cdot 59(40 \%)$ \\
1992 & $7 \cdot 79$ & $6.61(28 \%)$ \\
Mean & $7 \cdot 38$ & $6 \cdot 20(31 \cdot 6 \%)$ \\
S.E. (D.F. = 3) & 0.663 & $1 \cdot 860$ \\
\hline \hline
\end{tabular}

of the grass/clover pasture, averaged over the 4 years, increased from $15 \%$ of the total OM yield in midApril, reaching a peak of $49-50 \%$ from late June to early August before declining to $15 \%$ by early October. During this peak of clover growth in midsummer, the grass/clover pasture marginally outyielded the grass $+\mathrm{N}$ pasture over a 6 -week period.

\section{Productivity of pastures as measured by steer liveweight gain $(L W G)$}

Spring turnout of steers onto the pastures was determined as described by Tyson et al. (1992a), i.e. by the amount of herbage available and the loadbearing capacity of the ground as measured by a hand-held shear vane (Serota \& Jangle 1972) and varied between 29 March and 20 April (Table 3). The

Table 1. Annual rainfall, maximum potential soil water deficit (SWD), drainage volume and duration

\begin{tabular}{|c|c|c|c|c|c|c|}
\hline $1983 / 84$ & 1144 & 268 & 1 Aug & 555 & $28 \mathrm{Nov}$ & $8 \mathrm{Apr}$ \\
\hline $1986 / 87$ & 1091 & 85 & $30 \mathrm{Jul}$ & $670 *$ & 20 Oct* & $9 \mathrm{Apr}$ \\
\hline $1987 / 88$ & 1103 & 198 & $2 \mathrm{Oct}$ & 620 & $10 \mathrm{Oct}$ & $4 \mathrm{Apr}$ \\
\hline $1988 / 89$ & 930 & 104 & 26 Jun & 510 & 27 Sep & 1 May \\
\hline $1989 / 90$ & 1199 & 347 & 8 Sep & 730 & $28 \mathrm{Oct}$ & $2 \mathrm{Mar}$ \\
\hline $1990 / 91$ & 929 & 302 & $18 \mathrm{Sep}$ & 480 & $20 \mathrm{Nov}$ & $10 \mathrm{Apr}$ \\
\hline $1995 / 96$ & 893 & 278 & $5 \mathrm{Sep}$ & 480 & $11 \mathrm{Nov}$ & $25 \mathrm{Apr}$ \\
\hline Mean & 1047 & 203 & $25 \mathrm{Aug}$ & 585 & $25 \mathrm{Oct}$ & 13 Apr \\
\hline
\end{tabular}

* Includes $50 \mathrm{~mm}$ of drainage recorded between mid-August and early September 1986.

† An additional $144 \mathrm{~mm}$ drainage was recorded in May, June and July 1993.

+ An additional $32 \mathrm{~mm}$ drainage was recorded between 17 and 22 May 1994.

$\S$ Includes $30 \mathrm{~mm}$ of drainage recorded between 14 and 22 September 1994. 
Table 3. Length of grazing season, steer grazing days (per ha) and annual liveweight gain (t/ha) from grass $+200 \mathrm{~kg} \mathrm{~N} / \mathrm{ha}$ and grass/clover pasture. Values are means of two replicates

\begin{tabular}{|c|c|c|c|c|c|}
\hline \multirow[b]{2}{*}{ Year } & \multirow[b]{2}{*}{ Length of grazing season } & \multicolumn{2}{|c|}{ Grazing days } & \multicolumn{2}{|c|}{ Liveweight gain } \\
\hline & & Grass $+\mathrm{N}$ & Grass/clover & Grass $+\mathrm{N}$ & Grass/clover \\
\hline 1989 & 3 Apr-7 Nov (218 d) & 1021 & 926 & $0 \cdot 96$ & $0 \cdot 78$ \\
\hline 1990 & $29 \operatorname{Mar}-7 \operatorname{Nov}(223 d)$ & 1201 & 929 & $1 \cdot 01$ & $0 \cdot 89$ \\
\hline 1991 & $11 \mathrm{Apr}-5$ Nov $(208 \mathrm{~d})$ & 1118 & 1028 & 1.07 & $0 \cdot 96$ \\
\hline 1992 & 8 Apr-23 Oct (198 d) & 1153 & 1032 & 1.02 & $0 \cdot 85$ \\
\hline 1993 & 31 Mar-20 Oct $(202 d)$ & 1081 & 921 & $0 \cdot 96$ & $0 \cdot 70$ \\
\hline 1994 & 20 Apr-1 Nov (195 d) & 1110 & 874 & $0 \cdot 98$ & $0 \cdot 81$ \\
\hline 1995 & 5 Apr-17 Nov (226 d) & 1238 & 943 & $0 \cdot 97$ & $0 \cdot 69$ \\
\hline Mean & 6 Apr-3 Nov (210 d) & 1132 & 950 & $1 \cdot 00$ & $0 \cdot 81$ \\
\hline \multicolumn{2}{|c|}{ S.E. $($ D.F. $=6)$} & $73 \cdot 1$ & $58 \cdot 4$ & $0 \cdot 040$ & $0 \cdot 098$ \\
\hline
\end{tabular}
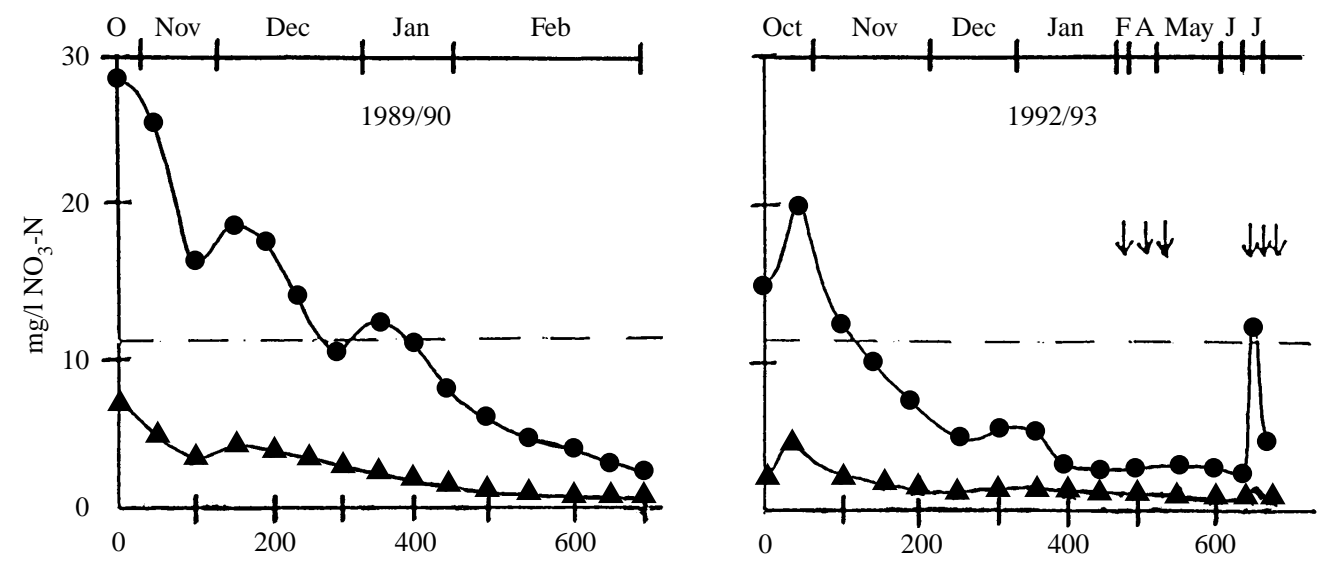

Accumulated drainage ( $\mathrm{mm})$
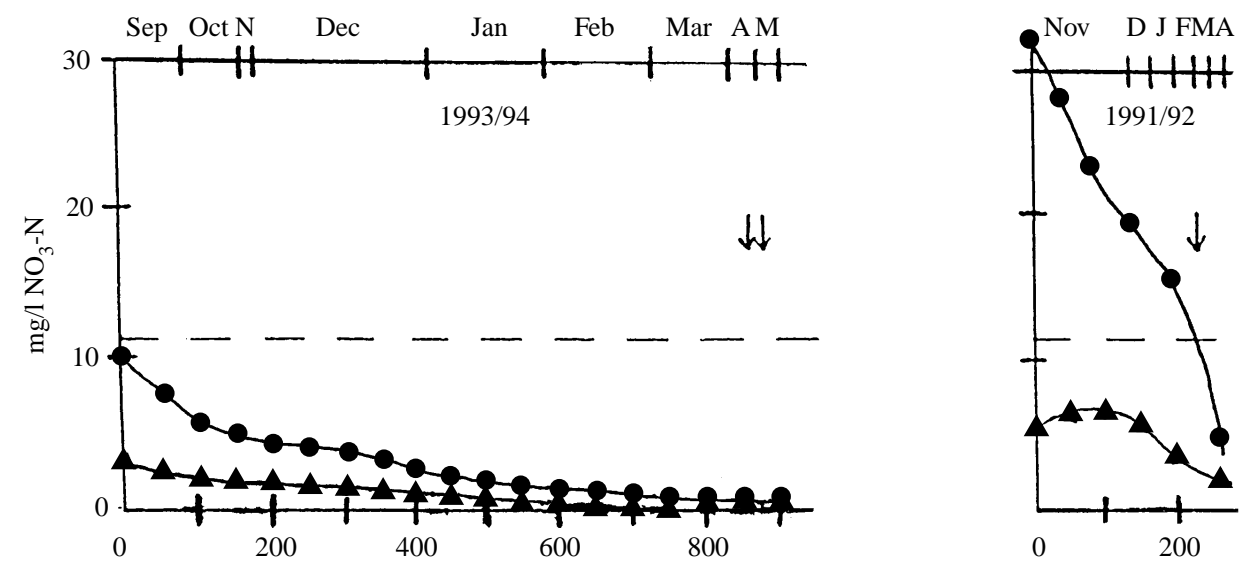

Accumulated drainage $(\mathrm{mm})$

Fig 1. Concentrations of $\mathrm{NO}_{3}-\mathrm{N}(\mathrm{mg} / \mathrm{l})$ in selected winter drainage periods from a grazed grass pasture receiving $200 \mathrm{~kg}$ $\mathrm{N} /$ ha per annum $(\bullet)$ and a grass/clover pasture receiving no artificial $\mathrm{N}(\boldsymbol{\Delta})$. Fertilizer added when indicated by arrows. Mean values from $2 \times 1$ ha paddocks for each treatment for the periods 1989/90, 1991/92, 1992/93 and 1993/94. The EU limit in drinking water is also indicated (--). There was no drainage in March 1993. 
Table 4. Loss of $N(\mathrm{~kg} / \mathrm{ha})$ by drainage from grass $+200 \mathrm{~kg} \mathrm{~N} / \mathrm{ha}$ and grass/clover pasture between 1988 and 1996. Values are means of two replicates

\begin{tabular}{lcc}
\hline \hline Year & Grass $+\mathrm{N}$ & Grass/clover \\
\hline $1988 / 89$ & $38 \cdot 3$ & $10 \cdot 4$ \\
$1989 / 90$ & $83 \cdot 5$ & $17 \cdot 9$ \\
$1990 / 91$ & $54 \cdot 3$ & $9 \cdot 1$ \\
$1991 / 92$ & $51 \cdot 6$ & $15 \cdot 4$ \\
$1992 / 93$ & $40 \cdot 4$ & $12 \cdot 2$ \\
$1993 / 94^{*}$ & $29 \cdot 6$ & $10 \cdot 2$ \\
$1994 / 95$ & $31 \cdot 8$ & $11 \cdot 2$ \\
$1995 / 96$ & $72 \cdot 5$ & $16 \cdot 6$ \\
Treatment mean & $50 \cdot 2$ & $12 \cdot 9$ \\
S.E. (D.F. = 7) & $19 \cdot 38$ & $3 \cdot 28$ \\
\hline \hline
\end{tabular}

* During the exceptionally wet summer of 1993 (Table 1) an additional $6.2 \mathrm{~kg} \mathrm{~N} /$ ha was leached from the grass $+\mathrm{N}$ pasture and $1.7 \mathrm{~kg} \mathrm{~N} /$ ha was leached from the grass/clover pasture. These values are included in the 1993/94 totals, i.e. in addition to winter drainage losses.

end of the grazing season was usually dictated by lack of available herbage rather than by soil condition. Annual liveweight production (Table 3 ) on the grass $+\mathrm{N}$ pasture was remarkably consistent from year to year, only varying over the 7 years between 0.96 and $1.07 \mathrm{t} / \mathrm{ha}$. Animal production on the grass/ clover pasture varied more from year to year (range $0.69-0.96 \mathrm{t} / \mathrm{ha}$ ) and over the first 4 years mirrored the clover content of the swards. Individual steer LWG values were also more consistent from year to year on the grass $+\mathrm{N}$ pasture $(0.78-0.96 \mathrm{~kg} /$ day, mean $0.88 \pm 0.044 \mathrm{~kg} /$ day) but over the 7 -year period were not significantly different from those of the steers grazing the grass/clover pasture $(0.73-0.96 \mathrm{~kg} / \mathrm{day}$, mean $0 \cdot 85 \pm 0 \cdot 090 \mathrm{~kg} /$ day).

\section{Nitrogen leaching losses from grass $+N$ pasture compared with grass/clover pasture}

Nitrogen as $\mathrm{NH}_{4}-\mathrm{N}$ was recorded at concentrations of $c .1 \mathrm{mg} / 1$ in the initial drainage each autumn but rapidly declined to $<0.1 \mathrm{mg} / \mathrm{l}$ throughout the remainder of the winter, so that only $\mathrm{NO}_{3}-\mathrm{N}$ concentrations are reported. Nitrite- $\mathrm{N}$ concentrations were assumed to be negligible. The mean concentrations of $\mathrm{NO}_{3}-\mathrm{N}$ in the drainage waters from both pastures are shown in Fig. 1 for selected winters. The $\mathrm{NO}_{3}-\mathrm{N}$ in the drainage water of winter 1989/90 illustrates the high concentrations recorded after a hot, dry summer with a large potential SWD (Table 1) and can be contrasted with the lower $\mathrm{NO}_{3}-\mathrm{N}$ concentration in the drainage water of 1993/94 following a cool, wet summer with a small potential SWD. The winter of 1991/92 was dry, with less than half the average winter drainage and illustrates a rapid decline in $\mathrm{NO}_{3}-$ $\mathrm{N}$ concentration from late February 1992. The final
Table 5. Loss of $N(\mathrm{~kg} / \mathrm{ha})$ by drainage from grass $+200 \mathrm{~kg} \mathrm{~N} /$ ha pasture between 1983 and 1988 prior to the comparison with grass/clover pasture. Values are means of two replicates

\begin{tabular}{lc}
\hline \hline Year & Grass $+\mathrm{N}$ \\
\hline $1983 / 84$ & $62 \cdot 0$ \\
$1984 / 85$ & $69 \cdot 4$ \\
$1985 / 86$ & $61 \cdot 8$ \\
$1986 / 87$ & $35 \cdot 3$ \\
$1987 / 88$ & $62 \cdot 8$ \\
Treatment mean & $58 \cdot 2$ \\
S.E. $($ D.F. $=4)$ & $13 \cdot 23$ \\
\hline \hline
\end{tabular}

illustration shows the $\mathrm{NO}_{3}-\mathrm{N}$ concentration in the drainage water during the very wet spring and summer of 1993, with monthly inputs of $\mathrm{N}$ to the grass pasture and intermittent drainage recorded from April to July. Each winter there was a similar trend in the $\mathrm{NO}_{3}-\mathrm{N}$ concentrations in the drainage water from both treatments (Fig. 1). Highest concentrations of $\mathrm{NO}_{3}-\mathrm{N}$ occurred in the first $50 \mathrm{~mm}$ of drainage each autumn and then declined throughout the winter to reach $<5 \mathrm{mg} / 1$ from the grass $+\mathrm{N}$ pasture and $<$ $1 \mathrm{mg} / 1$ from the grass/clover pasture by late March, provided that $>500 \mathrm{~mm}$ of winter drainage had occurred. Also shown in Fig.1 is the maximum permissible level of $\mathrm{NO}_{3}-\mathrm{N}(11.3 \mathrm{mg} / \mathrm{l})$ allowed in drinking water by the European Union (EU).

The quantity of $\mathrm{N}$ lost to drainage was calculated by using the values for weekly drainage volume and mean $\mathrm{NO}_{3}-\mathrm{N}$ concentration recorded in each week's drainage (Table 4). It was valid to use mean concentrations, as variable flow rates have been shown to have only a small effect on $\mathrm{NO}_{3}-\mathrm{N}$ concentration over short periods at this site (Scholefield et al. 1993). There were large annual variations in $\mathrm{N}$ loss from the grass $+\mathrm{N}$ treatment, ranging from $29.5 \mathrm{~kg} / \mathrm{ha}(1993 / 94)$ to $83.5 \mathrm{~kg} / \mathrm{ha}$ (1989/90). Nitrogen loss from the grazed grass/clover pasture over the 8 years was $26 \%$ of that recorded from the grass $+\mathrm{N}$ treatment.

The two grass replicate pastures being used in the current comparisons of animal output and $\mathrm{N}$ leaching loss with that recorded from grass/clover pasture had received the same treatment for 13 consecutive years (1983-95). The $\mathrm{N}$ losses by drainage from the grass + $\mathrm{N}$ pasture for the 5-year period prior to those reported in Table 4 are given in Table 5.

\section{DISCUSSION}

Farmers in the UK, as elsewhere in Europe, are under increasing pressure from the EU, National Governments and environmental organizations to reduce losses or outputs of agricultural chemicals into the environment. The increasing concern over $\mathrm{NO}_{3}$ in 
river and ground water has led to the EU upper limits of $11.3 \mathrm{mg} \mathrm{N} / 1$ for the $\mathrm{NO}_{3}-\mathrm{N}$ content of drinking water. The UK government has recently declared $\mathrm{NO}_{3}$ vulnerable zones with voluntary restrictions on $\mathrm{N}$ inputs to crops by farmers. There is a financial and environmental benefit in being able to maintain high levels of animal output by using minimum inputs of fertilizer, or by relying on clover-based pastures to fix the $\mathrm{N}$ required to maintain productive pastures with minimal contamination of rivers and ground waters. However, Jarvis (1992) argued that if animal output from a clover-based pasture was similar to that from $\mathrm{N}$-fertilized grass pasture, this would imply that similar quantities of $\mathrm{N}$ were circulating around the two systems, so that $\mathrm{NO}_{3}$ leaching losses would be similar. Macduff et al. (1990) demonstrated that under a sheep-grazed clover monoculture, the concentration of $\mathrm{NO}_{3}-\mathrm{N}$ in the soil solution below the rooting zone was comparable to that below highly fertilized grass pastures $(400 \mathrm{~kg} \mathrm{~N} / \mathrm{ha})$. Cuttle et al. (1992) studied $\mathrm{NO}_{3}-\mathrm{N}$ leaching losses from sheepgrazed pastures over a period of 3 years and recorded a winter loss of $2-24 \mathrm{~kg} \mathrm{~N} / \mathrm{ha}$ from grass plots fertilized with $150-200 \mathrm{~kg} \mathrm{~N} /$ ha per year compared with $6-33 \mathrm{~kg} \mathrm{~N} /$ ha from grass/clover plots.

It has already been demonstrated (Tyson et al. 1993) that increasing $\mathrm{N}$ input from 200 to $400 \mathrm{~kg} / \mathrm{ha}$ led to only a marginal, uneconomical, increase in animal output. The additional $\mathrm{N}$ lost to drainage from the drained pasture given $400 \mathrm{~kg} \mathrm{~N} /$ ha, however, caused the $\mathrm{NO}_{3}-\mathrm{N}$ in the drainage water to exceed the EU limit throughout most winters. Initial concentrations of $\mathrm{NO}_{3}-\mathrm{N}$ were as high as $70 \mathrm{mg} / 1$ in October 1989 and averaged $55 \mathrm{mg} / \mathrm{l}$ at this time over 7 years. The total loss of $\mathrm{N}$ by leaching averaged $194 \mathrm{~kg} \mathrm{~N} / \mathrm{ha}$ each winter, the equivalent of $48 \cdot 5 \%$ of that applied as fertilizer $\mathrm{N}$. In contrast, when no fertilizer $\mathrm{N}$ was applied to a grass-only pasture, losses were much lower, averaging $5 \mathrm{~kg} \mathrm{~N} /$ ha annually (Scholefield et al. 1993; Tyson et al. 1993)

Estimates of herbage production on grazed pastures are notoriously difficult to make and the use of exclusion cages, as used in this experiment, has been criticized (Parsons et al. 1984). Although they do not give a measure of herbage consumed by the grazing animal, cages give a measure of the productivity of a pasture which has been previously grazed with returns of animal excreta. Estimates of the clover content of a grazed pasture can also be criticized if based on non-grazed areas under exclusion cages, even if the grazing animal is excluded for only 21 days. Accepting these criticisms, estimates of herbage production in the present study revealed a $15 \%$ lower OM yield from the grass/clover pasture over a 4-year period when compared with the grass $+\mathrm{N}$ pasture. Clover content, averaged over the 4 years, increased as the growing season progressed, reaching a peak contribution of c. $50 \%$ of the total yield in mid-summer.
The $15 \%$ lower OM production from the grass/ clover pasture resulted in a corresponding reduction of $16 \%$ in grazing days (or 0.7 steers/ha per day) compared with the grass $+\mathrm{N}$ pasture (Table 3). This lower stocking density on the grass/clover pasture might have been compensated for by an enhanced daily LWG. Increased growth rates have been demonstrated by cattle fed on forages made from white clover compared with those from grass in indoor feeding trials (Cook \& Wilkins 1981; Thomson 1984). However, in grazing experiments with steers on grass/clover pastures, such responses are more difficult to demonstrate (Clark 1988). In the present experiment, growth rates by steers on the grass/clover pasture, averaged over the 7-year period $(0.85 \mathrm{~kg} /$ day $)$, were similar to the growth rates of steers grazing the $\mathrm{N}$-fertilized grass pasture $(0.88 \mathrm{~kg} /$ day $)$.

Although annual steer production per hectare from the grass pasture was $190 \mathrm{~kg}$ greater than that achieved from the grass/clover pasture, in monetary terms when the cost of buying and applying $200 \mathrm{~kg} \mathrm{~N} / \mathrm{ha}$ to the grass pasture is taken into consideration, the value of this extra animal production is reduced. Using late 1995 prices (Nix 1995), the additional LWG produced annually from the grass $+200 \mathrm{~kg} \mathrm{~N}$ pasture was valued at $£ 218(£ 1.15 / \mathrm{kg})$. Set against this extra income, the cost of $200 \mathrm{~kg} \mathrm{~N}(£ 72.50)$ and the $£ 41 /$ ha cost of applying $\mathrm{N}$ fertilizer on six occasions reduced the advantage of the grass $+200 \mathrm{~kg} \mathrm{~N}$ pasture to $£ 105 / \mathrm{ha}$, with no allowance being made for the higher working capital involved in the more heavily stocked grass $+\mathrm{N}$ treatment.

The major advantage shown by the clover-based pasture over the $\mathrm{N}$-fertilized grass pasture was the very much lower loss of $\mathrm{N}$ by leaching. Approximately four times as much $\mathrm{N}$ leached from the $\mathrm{N}$-fertilized grass each winter $(50 \mathrm{~kg})$ than from the grass/clover pasture $(13 \mathrm{~kg})$. The concentration of $\mathrm{NO}_{3}-\mathrm{N}$ in the leachate from the grass/clover pasture never exceeded the EU limit for drinking water at any time, whereas in all but two of the years the $\mathrm{NO}_{3}-\mathrm{N}$ concentration from the grass $+\mathrm{N}$ pasture was above the EU limit at the onset of drainage in autumn. Concentration of $\mathrm{NO}_{3}-\mathrm{N}$ in the leachate from the grass $+\mathrm{N}$ pasture was as high as $30 \mathrm{mg} / 1$ in October 1989 (Fig. 1) and in November 1991.

A possible explanation for the large difference in $\mathrm{NO}_{3}-\mathrm{N}$ loss from the two contrasting pastures could be their previous history. The $\mathrm{N}$-fertilized grass pasture has, to our knowledge, not been ploughed for at least 50 years. The organic matter status in the top soil horizons was high $(5.7 \% \mathrm{C}$ and $0.51 \% \mathrm{~N}$ in the upper $10 \mathrm{~cm}$ of the soil profile). Soil sampling each October revealed only small differences in total soil $\mathrm{N}$ to $10 \mathrm{~cm}$ depth from year to year with no obvious changes (Tyson et al. 1993). Therefore, organic matter accumulation was apparently at or approaching 


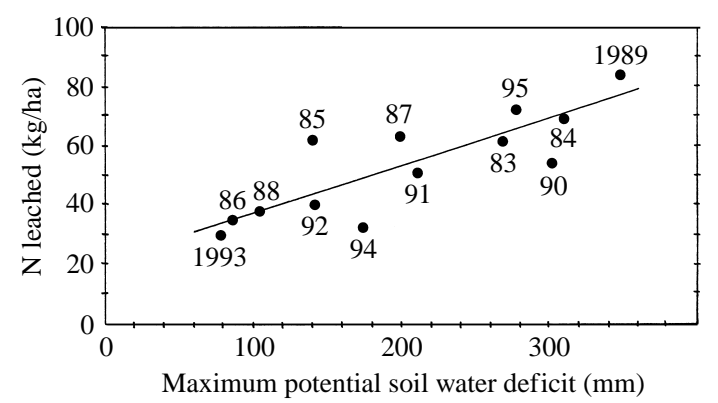

Fig 2. The relationship between the maximum potential soil water deficit $(\mathrm{mm})$ recorded each summer over a 13-year period (1983-95) and the subsequent loss of $\mathrm{NO}_{3}-\mathrm{N}(\mathrm{kg})$ by leaching from grazed grass pasture receiving $200 \mathrm{~kg} \mathrm{~N} / \mathrm{ha}$ per annum. $y=21 \cdot 7+156 x, r=0.814, P<0.001$.

equilibrium. Surplus N not removed either in the animal LWG, by denitrification or by ammonia volatilization would have been leached in the following winter's drainage. The grass/clover paddocks had, in contrast, originally been ploughed and reseeded with perennial ryegrass in August 1982. A flush of mineralization occurred after ploughing, causing a drop in the soil organic matter status of the top $10 \mathrm{~cm}$ of the soil profile to $4.0 \% \mathrm{C}$ and $0.37 \% \mathrm{~N}$, a loss of $c .17 \mathrm{t} /$ ha of $\mathrm{C}$ and $1.4 \mathrm{t} / \mathrm{ha}$ of $\mathrm{N}$ (Tyson et al. 1993). Since ploughing in 1982, the soil $\mathrm{N}$ to $10 \mathrm{~cm}$ depth increased at a rate of $c .80 \mathrm{~kg} \mathrm{~N} /$ ha annually. This increase in soil $\mathrm{N}$ under a newly sown grass pasture was similar to the annual increase measured elsewhere during the first 10 years under a newly established grass/clover pasture on a free draining sandy-loam soil of the Frilsham series (Tyson et al. 1990). Since conversion in 1988 to a grass/clover pasture, soil $\mathrm{N}$ at the North Wyke site has continued to increase so that approximately half of the original loss of organic $\mathrm{N}$ had been restored by 1995. It seems likely, therefore, that as the high $\mathrm{N}$ values found in the soil under the old grass pasture are approached under the grass/clover pasture, a decreasing quantity of $\mathrm{N}$ will be incorporated into the soil organic matter, leaving more surplus $\mathrm{N}$ to be leached. Comparison of undisturbed and reseeded grass pastures at the same site (Scholefield et al. 1993) showed that over the 5 years after reseeding, $\mathrm{NO}_{3}-\mathrm{N}$ leaching losses were, on average, $50 \%$ lower from the reseeded pasture than from the permanent pastures. This effect may also be the case for the present treatments over an extended period.

Another important effect may be through the difference in stocking rates, i.e. the higher stocking rate with the grass $+\mathrm{N}$ pasture may have given rise to greater excesses and leaching losses of $\mathrm{N}$. Differences in the quantities of $\mathrm{N}$ leached from other pastures in the experimental area (Scholefield et al. 1993) receiving 200 or $400 \mathrm{~kg} \mathrm{~N} /$ ha demonstrate that only relatively small differences in animal output may result in large differences in leaching losses. Other studies with grazing sheep (Cuttle et al. 1992) have also shown that there is a strong positive relationship between livestock carried and leached $\mathrm{NO}_{3}-\mathrm{N}$, regardless of whether $\mathrm{N}$ is supplied through fertilizer addition or by biological fixation.

\section{Leaching losses from $\mathrm{N}$-fertilized grazed grass pasture over the long term}

It was apparent that a greater loss of $\mathrm{NO}_{3}$ followed dry summers and a lower loss followed wet summers. There was an approximately three-fold difference between the lowest and the highest winter loss recorded in the 13-year period. In Fig. 2, the loss of $\mathrm{N}$ measured each winter is plotted against the maximum potential SWD recorded in the preceding summer (from Table 1). The average throughput of winter drainage $(585 \mathrm{~mm})$ resulted in low concentrations of $\mathrm{NO}_{3}-\mathrm{N}$ by early spring (Fig. 1) and in the leaching of $90 \%$ or more of the residual $\mathrm{NO}_{3}$ remaining in the soil profile at the end of the grazing season (Scholefield et al. 1993). The quantity of $\mathrm{N}$ leached each winter was highly correlated $(P<0.001)$ with the maximum potential SWD recorded during the preceding summer. (A similar relationship $(P<0 \cdot 1)$ was also shown by the grass/clover pasture.) The greater loss during winters following a dry summer could result from some of the $\mathrm{N}$ applied as fertilizer remaining in the soil during drought conditions. Much lower rates of denitrification would occur in drought conditions and if the soil wetting up process occurred while soil temperatures were still optimal, a burst of mineralization could occur, releasing yet more mineral $\mathrm{N}$, surplus to the sward's need, to be in the soil profile and at risk of leaching loss.

Using Fig. 2, it is possible to predict with a high degree of accuracy the quantity of $\mathrm{N}$ to be leached each winter. Exceptions will occur during some winters, as illustrated by the greater $\mathrm{N}$ loss than predicted in 1985/86 and the lower than predicted loss in 1994/95. During March 1986 up to $10 \mathrm{~kg} \mathrm{~N}$ from the first spring fertilizer application was leached from the soil profile during a very cold month, with minimal grass growth, so adding to the total loss. During the autumn of 1994, however, the reverse was true when exceptionally mild weather after the removal of the steers on 1 November resulted in considerable grass growth and uptake of $\mathrm{N}$ continuing until mid-December, thereby reducing the pool of $\mathrm{NO}_{3}-\mathrm{N}$ in the soil profile at risk of loss. When winters are abnormally dry, as was the case in 1991/92, incomplete leaching of $\mathrm{N}$ occurs. The very rapid fall in $\mathrm{NO}_{3}-\mathrm{N}$ concentration in the drainage water measured during late February and March 1992 (Fig. 1) was probably caused by $\mathrm{N}$ uptake by a rapidly growing sward that followed a mild early spring. 


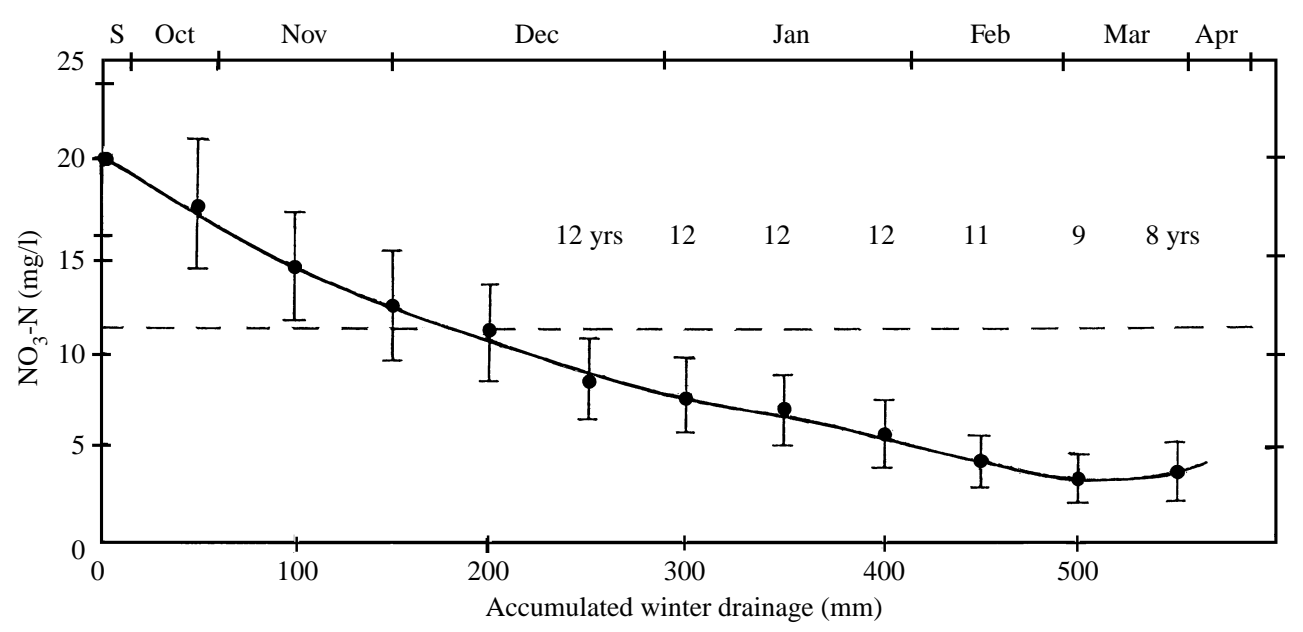

Fig 3. Mean concentration of $\mathrm{NO}_{3}-\mathrm{N}(\mathrm{mg} / \mathrm{l})$ in winter drainage from the grazed grass pasture receiving $200 \mathrm{~kg} \mathrm{~N} / \mathrm{ha}$ per annum. Based on the 13-year period 1983-95 unless otherwise indicated. The EU limit in drinking water is also indicated (--). Vertical bars represent s.E.s.

\section{Nitrogen losses from spring applications of fertilizer- $N$}

Data presented in Fig. 1 and confirmed in several other years demonstrate that there was little effect of the first spring application of $\mathrm{N}$ in mid-March on the $\mathrm{NO}_{3}-\mathrm{N}$ concentration in the drainage water. A small increase in $\mathrm{NO}_{3}-\mathrm{N}$ concentration occurred in March 1985, a larger increase in March 1986 (see above) and a small increase in March 1988. Applications of $\mathrm{N}$ in April 1985, March 1991 and March 1992 caused no increase in the $\mathrm{NO}_{3}-\mathrm{N}$ concentration. These first spring applications of $\mathrm{N}$ during March, at rates of $22-25 \mathrm{~kg} / \mathrm{ha}$ and at a time when grass growth was beginning, could be expected to be taken up fairly rapidly and therefore not to be at risk of loss by leaching during further wet spells of weather in March and April. Even the two applications of $40 \mathrm{~kg}$ N/ha on 14 April and 6 May 1994 (Fig. 1) caused only a small increase in $\mathrm{NO}_{3}-\mathrm{N}$ in the $46 \mathrm{~mm}$ of drainage that occurred between 17 and 27 May 1994.

The spring and early summer of 1993 was an exceptionally wet period, with $432 \mathrm{~mm}$ of rain recorded during April-July compared with the 30year mean rainfall for these months of $240 \mathrm{~mm}$. The soil was restored to field capacity on no fewer than seven occasions between April and July and a total of $188 \mathrm{~mm}$ of drainage recorded (Fig. 1). However, despite the $174 \mathrm{~kg} \mathrm{~N} /$ ha applied during these months, only $6.9 \mathrm{~kg} \mathrm{~N} /$ ha was leached through the soil profile.

The small, or negligible, reaction to applications of early spring $\mathrm{N}$ in the $\mathrm{NO}_{3}-\mathrm{N}$ concentration in the drainage water during some wet springs and throughout the very wet summer of 1993 indicates that moderate inputs of $\mathrm{N}$ fertilizer were rapidly used by an actively growing sward or denitrified in the wet and warm soil. The converse would be true in dry summers, when poor grass growth and low denitrification due to drought allows a build up of unused $\mathrm{NO}_{3}{ }^{-}$ $\mathrm{N}$, leading to a large loss of $\mathrm{N}$ by leaching during the ensuing winter (Fig. 2).

\section{Generalized nitrate leaching pattern}

The 8 years' data on average $\mathrm{NO}_{3}-\mathrm{N}$ leaching concentrations throughout each winter from the two $\mathrm{N}$-fertilized grazed grass pastures used in conjunction with the previous 5 years' data from these pastures allow values to be estimated for the average $\mathrm{NO}_{3}-\mathrm{N}$ concentration to be expected from a grazed grass pasture fertilized with $200 \mathrm{~kg} \mathrm{~N} /$ ha under the sitespecific conditions of soil type, sward age, drainage status and climate relating to North Wyke, Devon (Fig. 3).

At North Wyke, the average maximum potential SWD of $203 \mathrm{~mm}$ (c. $100 \mathrm{~mm}$ actual SWD), recorded over the 13-year period, was reached in late August (Table 1) followed by a 2-month soil wetting up period, so that first drainage occurred during late October (Table 1). This initial drainage contained on average $20 \mathrm{mg} / 1 \mathrm{NO}_{3}-\mathrm{N}$. The $\mathrm{NO}_{3}-\mathrm{N}$ concentration declined steadily throughout the winter period, dropping below the EU limit in drinking water after c. $150 \mathrm{~mm}$ of accumulated drainage in early December and continued to decline to $c .3 \mathrm{mg} / 1 \mathrm{NO}_{3}-\mathrm{N}$ by early March after $500 \mathrm{~mm}$ of accumulated drainage. The first spring application of $\mathrm{N}$ fertilizer in mid-March resulted in a very small increase in $\mathrm{NO}_{3}-\mathrm{N}$ by the end of winter drainage during early April. Over the 13year period, on average, $53 \mathrm{~kg} \mathrm{~N} /$ ha was leached each winter, equivalent to $26 \%$ of that applied annually as fertilizer-N. 


\section{REFERENCES}

Armstrong, A. C. \& Garwood, E. A. (1991). Hydrological consequences of artificial drainage of grassland. Hydrological Processes 5, 157-174.

Clark, H. (1988). Beef and sheep output from grass/white clover swards. In Proceedings of a RASE/ADAS Conference. The Grassland Debate-White Clover $v$ Applied Nitrogen, pp. 12-16. Stoneleigh, Warwickshire: Royal Agricultural Society of England.

Cook, J. E. \& Wilkins, R. J. (1981). The feeding value of white clover silage. In Proceedings of the 6th Silage Conference, Edinburgh (Eds R. D. Harkess \& M. E. Castle), pp. 41-42. Edinburgh: Edinburgh University.

Cowling, D. W. (1982). Biological nitrogen fixation and grassland production in the United Kingdom. Philosophical Transactions of the Royal Society of London, Series B 296, 397-404.

Cuttle, S. P., Hallard, M., Daniel, G. \& Scurlock, R. V. (1992). Nitrate leaching from sheep-grazed grass/clover and fertilized grass pastures. Journal of Agricultural Science, Cambridge 119, 335-343.

Harrod, T. (1981). The Soils of North Wyke and Rowden. Technical Report by the Soil Survey of England and Wales commissioned by AFRC Institute of Grassland and Environmental Research, North Wyke Library.

Hendriksen, A. \& Selmer Olsen, A. R. (1970). Automatic methods for determining nitrate and nitrite in water and soil extracts. Analyst 95, 514-518.

Holmes, C. W. (1974). The Massey grassmeter. In Dairy Farming Annual 1974 (Ed. S. J. Rolston), pp. 26-30. Palmerston North, New Zealand: Massey University.

JARVIS, S. C. (1992). Nitrogen cycling and losses in clover based pastures. Herba 5, 56-59.

MacdufF, J. H., JARVIS, S. C. \& Roberts, D. H. (1990). Nitrates: leaching from grazed grass systems. In NitratesAgriculture-Eau (Ed. R. Calvet), pp. 405-410. Paris: INRA.

Nix, J. (1995). Farm Management Pocketbook. Wye College, University of London.
Parsons, A. J., Collett, B. \& Lewis, J. (1984). Changes in the structure and physiology of a perennial ryegrass sward when released from a continuous stocking management: implications for the use of exclusion cages in continuously stocked swards. Grass and Forage Science 39, 1-9.

Pascal, J. A. \& Sheppard, B. W. (1985) The development of a strip-seeder for sward improvement. Research and Development in Agriculture 2, 125-134.

Penman, H. L. (1952). Experiments on irrigation of sugar beet. Journal of Agricultural Science 42, 286-292.

Scholefield, D., Tyson, K. C., Garwood, E. A., Armstrong, A. C., Hawkins, J. \& Stone, A. C. (1993). Nitrate leaching from grazed grassland lysimeters: effects of fertilizer input, field drainage, age of sward and patterns of weather. Journal of Soil Science 44, 601-613.

SeArle, P. L. (1984). The Berthelot or indophenol reaction and its use in the analytical chemistry of nitrogen. Analyst 109, 549-568.

Serota, S. \& Jangle, A. (1972). A direct-reading pocket shear vane. Civil Engineering, ASCE, January 1991.

Thomson, D. J. (1984). The nutritive value of white clover. British Grassland Society Occasional Symposium 16, 78-92.

Tyson, K. C., Roberts, D. H., Clement, C. R. \& Garwood, E. A. (1990). Comparison of crop yields and soil conditions during 30 years under annual tillage or grazed pasture. Journal of Agricultural Science, Cambridge 115, 29-40.

Tyson, K. C., Garwood, E. A., Armstrong, A. C. \& SCHOLEFIELD, D. (1992a). Effects of field drainage on the growth of herbage and the liveweight gain of grazing beef cattle. Grass and Forage Science 47, 290-301.

Tyson, K., Hawkins, J. \& Stone, A. (1992b). The North Wyke grassland drainage experiment. Grass Farmer 42, 21-23.

Tyson, K. C., Hawkins, J. M. B. \& Stone, A. C. (1993). Final report on the AFRC-ADAS drainage experiment 1982-1993. IGER Technical Report. North Wyke, Devon. 